\title{
Determinants Of Credit Sources Utilized By Small Scale Arable Crop Farmers In Imo State, Nigeria
}

\author{
Ben-Chendo G. N. \\ Department of Agricultural Economics \\ Federal University of Technology, Owerri \\ Imo state, Nigeria \\ Oshaji. I. \\ Department of Agricultural Economics \\ Federal University of Technology, Owerri \\ Imo state, Nigeria \\ Iweanya G. \\ Department of Agricultural Economics \\ Federal University of Technology, Owerri \\ Imo state, Nigeria
}

\begin{abstract}
Credit is not only one of the critical inputs in agriculture but is also an effective means of rural development. The study determined the sources utilized by small-scale arable crop farmers in Imo state, Nigeria. 80 respondents were randomly selected from 16 villages in one local government area selected at random among the 27 local government areas in Imo state, Nigeria and interviewed using structured questionnaire. The data were collected and analysed using descriptive statistics such as mean, percentages and frequency distributions and Multinomial logit regression model. The study revealed that majority $(41.25 \%)$ of the farmers in the study area were middle-aged farmers between the ages of 30-49years and equal number of male and female arable crop farmers in the study area were interviewed of which majority $(78.75 \%)$ were married and also had basic education $(82.5 \%)$. The major source of credit utilized by the respondents in the study area is esusu (30\%) followed by village cooperatives $(17.5 \%)$ and then family and friends $(12.5 \%)$. Results showed that very few farmers in the area used credit from banks (2.5\%). Furthermore, the likelihood ratio statistics as indicated by $2(80.84)$ are highly significant and had strong explanatory power to predict farmers choices. Household size, interest rate, farm size, value of assets and age were the major significant determinants of credit sources. It is recommended that credit should be extended more to respondents with higher age and low family size and credit institutions should reduce the long process involved in obtaining loan from their institutions.
\end{abstract}

Keywords: Determinants, Credit, Credit sources, Small scale, Farmers, Imo state.

\section{INTRODUCTION}

Agriculture, being the act of cultivating crops and rearing livestock for human consumption, plays a very important role in the development of a nation. Agriculture acts as a fundamental source of income, feeding, and full employment for Nigerians. According to the Nigerian Agricultural Policy Document, the role of Nigerian agricultural sector includes provision of food for the growing population, foreign exchange earnings, employing a significant part of the 
labour force and providing income for farming households (Federal Ministry of Agriculture and Natural Resources (FMANR), 2010).

Agricultural credit plays important roles in making farming more productive and efficient in developing countries especially Nigeria. Empirical evidence has established a positive link between the declining agricultural productivity and limited credit facilities. Agriculture in prehistoric period sustained humanity over the years with little or no significant attachment to capital for production. However, in this modern time, inadequate credit has constituted a major constraint in expanding production as these small scale farmers have little or no capital to expand production.

According to Agborlahor et al, (2012), credit is a means of obtaining resources at a certain period of time with an obligation to pay it at a stated period in accordance with the terms and conditions of the credit obtained. The need for credit in the agricultural sector to foster its development is quite enormous. The problem is not unavailability of credit, the problem is inadequacy of credit, inability of credit to circulate and be sufficient for these farmers. Supplying credit to farmers will help the rural poor farmer produce for the market, generate cash surpluses and accumulated savings will be the basis for future income growth (Ehigiamusoe, 2008). Adofu et al, (2010), also identified that agricultural credit enhances productivity and promotes standard of living by breaking the vicious cycle of poverty. The problem is that this cycle is yet to be broken; seeing that $70 \%$ of farmers producing available food in the country are small scale farmers whose scale of operation is low due to low inputs and low income (John and Charles, 2015).

These small scale farmers may never be able to purchase more land, healthy seeds, modernized tools and equipment, increased labour (workforce) and other requirements necessary to expand production with the little income they make from this production scale. This is where the need for credit comes to play. Inadequate credit has been identified as a major problem confronting the development of the agricultural sector because all aspects of agricultural production require capital (Nwaru and Onuoha, 2010).

According to Omonona et al, (2010), access to credit enhances the production efficiency of small scale farmers thereby reducing rural poverty and food insecurity. It influences farm productivity since credit-constrained farmers are more likely to use lower levels of input in production compared to those who are not. Improving access to credit therefore has the capacity to facilitate optimal input use leading to a positive impact on productivity. Despite the importance of credit to farmers and some credit institutions created by the government, farmers still face challenges in the acquisition of credit which makes most of them to get easily discouraged and relent in their effort to contribute to the productivity of the agricultural sector. For this reason, this study seeks to find out the factors that determine credit sources which these small scale farmers in Imo state utilize.

Despite all the programmes and policies set for credit mobilization, one of the problems confronting small scale farmers in Nigeria is inadequate capital. Evidence has shown that poor access to credit has been a major problem to small scale farmers. According to Mgbakor et al, (2014), efforts made by the rural farmers to get financial assistance are always constrained by unnecessary strings attached to the credit services, especially collaterals used for assessing the borrower's credit worthiness; delay in release of loan (mostly offseason), and unfavourable payment terms for agricultural based activities by commercial banks (Adeniji et al, 2008). Therefore this study is not only important but timely due to the rising level of interest rates, heavy collaterals and requirements, tedious procedures and untimely disbursement of loan 
making credit acquisition seem almost impossible. This study will therefore be relevant to the Imo state government, Ministries of Agriculture and rural development, National planning commission and other agricultural agencies in Nigeria.

\section{Specific objectives were:}

1. Describe the socio-economic characteristics of small-scale arable crop farmers in Imo state.

2. Identify sources of agricultural credit available to small-scale farmers in Imo state.

3. Determine the socio-economic factors that influence agricultural credit source of farmers in the area.

\section{Hypothesis of the Study}

The understated hypothesis was tested:

$\mathbf{H}_{01}$ : There is no significant relationship between the socio-economic characteristics of the farmers and the type of credit sources which they utilize.

\section{METHODOLOGY}

The study was conducted in Imo state, Nigeria. The state is made up of twenty seven (27) local government areas. In this work, multistage sampling technique was adopted. In the first stage, simple random technique was used to select one local government area out of the twenty seven in Imo state. In the second stage, 16 villages were selected purposively from 85 villages in the local government area based on the level of farming activities. In the third stage, 5 farmers were randomly selected from each of the villages selected in the second stage. This gave a total of 80 respondents. Data were collected from primary and secondary information sources. The primary data were collected from the field survey using questionnaire together with interview schedule. The secondary data were collected from existing literature review such as reports, books, journals, newsletters, pamphlets, research projects and relevant books, information from the library, and internet. Objectives 1 and 2 were achieved using descriptive statistical tools such as mean, frequency distributions and percentages while multinomial logit (MNL) regression model was used to determine the factors influencing the choice of a particular credit source among the credit users (objective 4). No credit source group was adopted as the base category. For this study, the multinomial model was specified as follows:

Where:

$$
\mathrm{f}\left(\mathrm{X}_{1}, \mathrm{X}_{2}, \mathrm{X}_{3}, \mathrm{X}_{4}, \ldots, \mathrm{Xn}, \mathrm{e}\right)
$$

Choices of credit source $(0=$ no credit source, $1=$ banks, $2=$ cooperatives, $3=$ esusu/ajo $4=$ moneylenders, $5=$ family and friends)

Gender (Dummy variable, $0=$ female, $1=$ male); Age (years); Educational level $(0=$ no formal education, $1=$ FSLC, $2=$ SSCE, $3=$ OND/NCE); Marital status (dummy: $0=$ single, $1=$ married); Household size (number of persons); Farm size (hectares); Non-farm income (naira); Interest rate $($ percent); = value of assets $($ depreciation); $=$ high transaction cost (Dummy: $1=y e s, 0=$ no); = Farming status (Dummy: part time=0, full time $=1$ ); = Farming experience (years); e = error term

The A priori expectation is mathematically expressed as:

$$
\mathrm{X}_{1}, \mathrm{X}_{3}, \mathrm{X}_{4}, \mathrm{X}_{5}, \mathrm{X}_{6}, \mathrm{X}_{7}, \mathrm{X}_{8}, \mathrm{X}_{9}, \mathrm{X}_{10}, \mathrm{X}_{11}, \mathrm{X}_{12}>0 ; \mathrm{X}_{2}<0
$$

It was expected that age would be negatively significant while the other variables would be positively significant. 


\section{Socio-economic Characteristics of Small Scale Farmers.}

Age: The result of this study shows that majority of the farmers were between the ages of 3049 years $(41.25 \%)$. The mean age of the respondents was 46.7 years. This means that majority of the respondents were middle aged farmers who are still active, vibrant and dynamic and are more likely to adopt innovations better and faster than their older counterparts. As the farmer gets older, his ability to withstand stress reduces hence he lacks the stamina to face the tediousness involved in farming, this dependency increases to the extent that his personal disposable income is no longer adequate to carry his family needs, thus giving rise to the demand for credit to meet his farm capital and family consumption needs. This finding is in line with that of Nwaru (2004) who opined that most young and middle-aged farmers are highly innovative and informed.

Gender: The result of the study shows that $50 \%$ of the farmers are male and $50 \%$ are female. This shows that male and female in the study area equally participate in farming activities and equally have access to utilize different credit sources. Adewale et al. (2003) observed that gender is not as hindrance to the active involvement in farming activities.

Level of Education: The result shows that $17.5 \%$ of farmers in the area had no formal education, 22.5\% had First School Leaving Certificate (FSLC) i.e. primary education, $42.5 \%$ had SSCE and its equivalents, $17.5 \%$ had OND/NCE. This means that majority of the farmers in this area has formal education, which could increase their access to information on the various credit sources and how to utilize the credit most favourable to them. This also agrees with the results of Ojukaiye (2001) who reported that education is an essential socio-economic factor that influences farmers' decision because of its effects on the awareness, perception, reception and quick adoption of innovation that can increase productivity.

Marital Status: Majority (78.75\%) of farmers in the area are married while $21.25 \%$ are single. This indicates that there are more farmers who are married than those who are single. This greater percentage of married farmers also shows that their major source of labour was family labour (Ibekwe et al, 2012).

Household Size: The mean Family size of the farmers was 5 persons. $43.75 \%$ had a family size of $1-5$ persons, $55 \%$ had $6-10$ persons, while $1.25 \%$ had $11-15$ persons as their family size. The mean of household size of the respondents is 5 persons. The result is slightly in line with the National Bureau of Statistics (NBS) (2010) which put average household size of southern Nigeria at 4 persons. This is also in line with Nwaiwu (2015) who found out that household in the south eastern Nigeria maintained a moderate household size. This implies that the farmer will work more with hired labour than family labour and would require credit to meet the labour need.

Farming Experience: As seen in the table below, the average farming experience of the

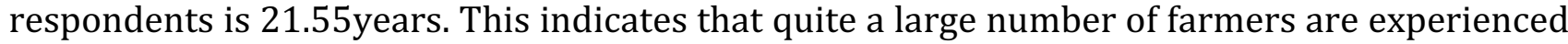
in farming activities. According to Nwaru et al (2004), the higher the farming experience, the more the farmers would have gained more knowledge and technical ideas on how to tackle farming problems and the higher would be the output and income. Also, this would increase the use of credit by the farmers in the area.

Farm Size: One of the major characteristics of small scale farming is fragmented landholding. The result of this study shows that $80 \%$ of farmers in the area cultivated on less than one hectare while $20 \%$ of farmers in the area farmed on between one to two hectares. This agrees 
with Ojukaiye (2001), classification of farm size of 0.1 hectares to 5.9 hectares as small farms. This implies that all the respondents were small scale farmers. This also implies that meaningful contribution to food security and increased agricultural output in the study area is not feasible.

Farming as Main Occupation: The table shows that $36.25 \%$ of the farmers had farming as their main occupation and $63.75 \%$ of the farmers are engaged in other economic activities. This implies that farming is not highly practiced or taken serious in the study area so they pay attention to other business and this in turn affect the outputs of the farm negatively and encourages credit diversification.

Occupation of Respondents: The table shows that (25\%) of the farmers take farming as their main occupation while $(12.50 \%)$ of farmers are civil servants, $(27.50 \%)$ are artisans, $(28.75 \%)$ are traders, $(5 \%)$ are drivers, $(1.25 \%)$ are security men. The implication of engaging in other economic activities among the respondents is that they are likely to pay more attention to the other activities than farming. This will affect their outputs and also their credit use as attention is not dedicated to farming business, this leads to low productivity as it affects their credit use. Ibekwe et al (2010) stated that non-farm activities have become an important component of livelihood strategies among rural households.

Non-farm Income: The results show that the average non-farm income of the respondents is 35525.75 naira. The table shows that majority $(71.25 \%)$ of the farmers have non-farm income of $0-49000$ naira, $20 \%$ of them have $50000-99000$ naira and $8.75 \%$ have 100,000 naira and above as their non-farm income. This implies that majority of the respondents have low income from their other occupation to support farming activities, hence increasing their need for credit facility. Also, Igbalajobi et al (2013) recorded in his work that majority of the rural poor are small-scale farmers and the poverty gap is becoming wider over time which calls for corrective action. 
Table 1: Socio-economic Characteristics of Small Scale Farmers

\begin{tabular}{|c|c|c|c|}
\hline & Frequency & Percentage (\%) & Mean \\
\hline \multicolumn{4}{|l|}{ Age (Years) } \\
\hline $20-29$ & 13 & 16.25 & 46.725 \\
\hline $30-39$ & 15 & 18.75 & \\
\hline $40-49$ & 18 & 22.5 & \\
\hline $50-59$ & 14 & 17.5 & \\
\hline $60-69$ & 10 & 12.5 & \\
\hline $70-79$ & 6 & 7.5 & \\
\hline $80-89$ & 4 & 5.0 & \\
\hline \multicolumn{4}{|l|}{ Gender } \\
\hline Male & 40 & 50 & \\
\hline Female & 40 & 50 & \\
\hline \multicolumn{4}{|l|}{ Educational Level } \\
\hline No formal education & 14 & 17.5 & \\
\hline FSLC & 18 & 22.5 & \\
\hline SSCE/Equivalents & 34 & 42.5 & \\
\hline OND/NCE & 14 & 17.5 & \\
\hline \multicolumn{4}{|l|}{ Marital Status } \\
\hline Single & 17 & 21.25 & \\
\hline Married & 63 & 78.75 & \\
\hline \multicolumn{4}{|l|}{$\begin{array}{l}\text { Household size } \\
\text { (No. of Persons) }\end{array}$} \\
\hline $1-5$ & 35 & 43.75 & 5.4375 \\
\hline $6-10$ & 44 & 55 & \\
\hline $11-15$ & 1 & 1.25 & \\
\hline \multicolumn{4}{|l|}{$\begin{array}{l}\text { Farming experience } \\
\text { (Years) }\end{array}$} \\
\hline $1-10$ & 26 & 32.5 & 21.55 \\
\hline $11-20$ & 27 & 33.75 & \\
\hline $21-30$ & 10 & 12.5 & \\
\hline $31-40$ & 9 & 11.25 & \\
\hline 41 and above & 8 & 10 & \\
\hline \multicolumn{4}{|l|}{ Farm size (Ha) } \\
\hline $0.20-0.49$ & 12 & 15 & 0.65 \\
\hline $0.50-0.79$ & 52 & 65 & \\
\hline $0.80-1.09$ & 9 & 11.25 & \\
\hline $1.10-1.39$ & 7 & 8.75 & \\
\hline \multicolumn{4}{|l|}{ Farmers occupation } \\
\hline Farming & 20 & 25 & \\
\hline Civil service & 10 & 12.50 & \\
\hline Artisans & 22 & 27.50 & \\
\hline Trading & 23 & 28.75 & \\
\hline Driving & 4 & 5.00 & \\
\hline Security service & 1 & 1.25 & \\
\hline \multicolumn{4}{|l|}{$\begin{array}{l}\text { Farming as Main } \\
\text { occupation }\end{array}$} \\
\hline Farming (Yes) & 29 & 36.25 & \\
\hline Farming (No) & 51 & 63.75 & \\
\hline \multicolumn{4}{|l|}{$\begin{array}{l}\text { Non-farm income } \\
\text { (naira) }\end{array}$} \\
\hline $0-49000$ & 57 & 71.25 & 35525.75 \\
\hline $50000-99000$ & 16 & 20 & \\
\hline $100000-149000$ & 3 & 3.75 & \\
\hline $150000-199000$ & 2 & 2.5 & \\
\hline 200000 and above & 2 & 2.5 & \\
\hline
\end{tabular}

Source: Field survey 2017

\section{Sources of Agricultural Credit Available to Small-scale Farmers in the Area}

The result of the study shows that $70 \%$ of the farmers in the area participate in credit utilization while $30 \%$ of the farmers do not participate in the use of credit for farming 
activities. This implies that majority of the farmers participate in the use of credit in the area hence increasing the chances of productivity in the area since credit enhances productivity.

Table 2: Distribution of farmers according to their participation in credit utilization

\begin{tabular}{lll}
\hline Credit utilization & Frequency & Percentage (\%) \\
\hline Yes & 56 & 70 \\
No & 24 & 30 \\
Total & 80 & 100 \\
\hline
\end{tabular}

Source: field survey, 2017

The result also shows the various sources of credit utilized by the respondents. $30 \%$ of the farmers in the area has no credit source and do not use credit, $2.5 \%$ of the farmers have credit from banks, $17.5 \%$ from cooperatives mainly village cooperatives, $30 \%$ from esusu i.e. village contributions, $6 \%$ from moneylenders and $10 \%$ of the farmers in the area got credit from family and friends. This implies that majority of farmers in the area choose esusu, family and friends and village cooperatives as their source of credit. According to the findings of Igbalajobi et al (2013), a good number of farming household had access to credit from friends and relatives, cooperatives, save and thrift in order to finance their farm and cater for their basic needs. Credit from non-institutional sources is more attractive, because there is little or no insistence on collateral security. On the other hand, formal sources of credit had low patronage from the farmers, which may be due to lack or limited presence of banks in the study area coupled with delay in approval and disbursement of loan and insistence on collateral security.

Table 3: Distribution of farmers according to the credit source available to them

\begin{tabular}{lll}
\hline Sources of credit & Frequency & Percentage (\%) \\
\hline Non-credit users & 24 & 30 \\
Banks & 2 & 2.5 \\
Cooperatives & 14 & 17.5 \\
Esusu & 24 & 30 \\
Moneylenders & 6 & 7.5 \\
Family and friends & 10 & 12.5 \\
Total & 80 & 100 \\
\hline
\end{tabular}

Source: Field Survey 2017 


\section{The Socio-economic Characteristics that Influence Farmers Credit Choice}

Table 4: Parameters of the Multinomial Logistic Model

\begin{tabular}{|c|c|c|c|c|c|}
\hline $\begin{array}{l}\text { Explanatory } \\
\text { variables }\end{array}$ & Banks & Cooperatives & Esusu & Moneylenders & $\begin{array}{l}\text { family and } \\
\text { friends }\end{array}$ \\
\hline \multirow[t]{2}{*}{ Age } & $-0.0194724^{* * *}$ & -0.0428599 & -0.048973 & $-0.18695^{* *}$ & $\begin{array}{l}- \\
0.1608487^{* * *}\end{array}$ \\
\hline & $(5.86)$ & $(0.92)$ & (1.39) & $(2.03)$ & $(3.46)$ \\
\hline \multirow[t]{2}{*}{ Gender } & 0.4606459 & $-1.951542^{* *}$ & -0.6342704 & -1.993778 & 0.3756191 \\
\hline & $(0.53)$ & (1.94) & $(0.77)$ & (1.10) & $(0.34)$ \\
\hline Marital & -0.6154995 & 1.101542 & -0.2630017 & $6.194158^{* *}$ & -0.1809245 \\
\hline Status & $(0.68)$ & $(0.98)$ & $(0.31)$ & $(2.18)$ & $(0.15)$ \\
\hline Household & $0.2891322^{*}$ & 0.3441389 & $0.3821399 * *$ & -0.8527372 & $0.4060889^{* *}$ \\
\hline Size & $(1.73)$ & $(1.64)$ & $(2.42)$ & $(1.35)$ & $(1.98)$ \\
\hline Farming & -0.4160294 & $-1.240218^{*}$ & -0.4728202 & -0.2657546 & 0.0983472 \\
\hline Status & $(0.86)$ & (1.67) & $(1.07)$ & $(0.24)$ & $(0.16)$ \\
\hline Nonfarm & $-2.60 \mathrm{E}-06$ & $-2.96 \mathrm{E}-05^{* * *}$ & $7.62 \mathrm{E}-07$ & -0.0000131 & $-7.53 \mathrm{E}-06$ \\
\hline Income & $(0.29)$ & $(3.08)$ & $(0.10)$ & $(0.66)$ & $(0.68)$ \\
\hline Educational & -0.5936922 & $0.8482294^{*}$ & $-0.9357528^{* * *}$ & 0.3822271 & -0.2973137 \\
\hline Level & $(1.55)$ & $(1.72)$ & $(2.61)$ & $(0.57)$ & $(0.59)$ \\
\hline \multirow[t]{2}{*}{ Farm size } & -0.0825633 & -0.4088753 & -0.1297983 & $-1.921539^{*}$ & $0.9775115^{* *}$ \\
\hline & $(0.27)$ & (1.16) & $(0.47)$ & $(1.94)$ & $(2.48)$ \\
\hline Farm & $0.0696811^{*}$ & 0.0071625 & $0.0984819^{* * *}$ & 0.0983233 & 0.613356 \\
\hline Experience & $(1.97)$ & $(0.14)$ & $(2.86)$ & $(1.50)$ & $(1.48)$ \\
\hline \multirow[t]{2}{*}{ Interest rate } & $-0.0002986^{* *}$ & $-0.0003872^{* * *}$ & $-0.0002553^{*}$ & $-0.0004314^{* *}$ & $-0.000375^{* *}$ \\
\hline & $(2.15)$ & $(2.65)$ & $(1.85)$ & $(2.47)$ & $\begin{array}{l}(2.38) \\
-\end{array}$ \\
\hline Transaction & $-0.0009121^{* * *}$ & 0.0000406 & -0.0000383 & -0.0032897 & $0.0006488^{* * *}$ \\
\hline Cost & $(2.95)$ & $(0.13)$ & $(0.13)$ & $(1.63)$ & $(1.84)$ \\
\hline \multirow[t]{2}{*}{ Depreciation } & 0.0000359 & 0.0000748 & 0.0000754 & $0.0001207^{* *}$ & 0.0000635 \\
\hline & $(0.71)$ & $(1.56)$ & $(1.60)$ & $(2.03)$ & $(1.30)$ \\
\hline \multirow[t]{2}{*}{ Constant } & -2.002347 & -0.7693765 & -0.9233583 & -3.456249 & -3.62677 \\
\hline & $(0.81)$ & $(0.27)$ & $(0.39)$ & $(0.71)$ & $(1.10)$ \\
\hline
\end{tabular}

Source: field survey 2017

Notes: $* * *, * *, *=$ significant at $1 \%, 5 \%$, and $10 \%$ probability level, respectively. Figures in parenthesis are coefficients showing $\mathrm{z}$-values

Base category $=$ No credit source

Number of observation $=80$

Log likelihood $=-93.331761$

LR chi2 $(60)=80.87$

Prob $>$ chi $2=0.0375$

Pseudo R2 $=0.3023$

In this analysis, no credit source was taken as the base category. The log likelihood is 93.331761, the likelihood ratio statistics as indicated by $=80.87$ are significant $(\mathrm{P}<0.0375)$. This suggests that the model has a strong explanatory power to predict farmers' choice of 
credit. Therefore, the study rejected the null hypothesis that there is no significant relationship between the socio-economic characteristics of the farmers and their choice of credit but accepted the alternative that there is significant relationship between the socio-economic characteristics of the farmer and their choice of credit.

In the bank model, the significant determinants affecting farmers choice of bank are age, interest rate and transaction cost, household size and farming experience. However, women and part time farmers are likely to choose cooperatives as their credit source. Non-farm income, educational level and interest rate also affect the respondents' choice of cooperatives as shown in table 4. According to Anjani (2007), the educational level was hypothesised to influence the choice of formal credit outlets positively. Household size, farming experience, educational level and interest rate are significant determinants for choosing esusu as a credit source. According to Anjani (2007) Different household types were supposed to influence the decision of credit differently. However, interest rate was negatively significant which implies that as interest rate of the source increases; the farmers are less likely to choose it.

In the Moneylenders model, age, farm size, interest rate, marital status and depreciation were significant determinants for the choice of this credit source. Married farmers are more likely to get credit from moneylenders than single farmers. Young farmers with smaller farm sizes are more likely to get credit from this source according to the results. This result is similar to that of Oboh and Ekpebu (2011) who found in his study that age and farm size have significant impact on credit allocation. Younger farmers with large household size and large farm size are more likely to get credit from family and friends. Also, as interest rate and transaction cost of acquiring credit from farmers increases, farmers become less likely to choose family and friends for credit supply.

\section{Marginal Effects of Credit Sources of the Farmers}

Table 5 below presents the estimated marginal effects and P-levels from the multinomial logistic model. 
Table 5: Marginal Effects of Multinomial Logistic Credit Source Choice Model

\begin{tabular}{|c|c|c|c|c|c|c|}
\hline $\begin{array}{l}\text { Explanatory } \\
\text { variables }\end{array}$ & $\begin{array}{l}\text { No credit } \\
\text { source }\end{array}$ & Banks & Cooperatives & Esusu & $\begin{array}{l}\text { Moneylender } \\
\mathrm{s}\end{array}$ & $\begin{array}{l}\text { Family and } \\
\text { friends }\end{array}$ \\
\hline Age & $\begin{array}{l}0.0058566 \\
(1.26)\end{array}$ & $\begin{array}{l}-0.015111^{* * *} \\
(28.98)\end{array}$ & $\begin{array}{l}-0.0010277 \\
(0.30)\end{array}$ & $\begin{array}{l}-0.0067889 \\
(0.98)\end{array}$ & $\begin{array}{l}0.0000455 \\
(0.34)\end{array}$ & $\begin{array}{l}-0.006207^{* * *} \\
(2.81)\end{array}$ \\
\hline Gender & $\begin{array}{l}-0.0146847 \\
(0.14)\end{array}$ & $\begin{array}{l}0.0904461 \\
(0.70)\end{array}$ & $\begin{array}{l}-0.1636855^{* *} \\
(1.99)\end{array}$ & $\begin{array}{l}-0.2704912 \\
(1.71)\end{array}$ & $\begin{array}{l}-0.0007981 \\
(0.33)\end{array}$ & $\begin{array}{l}0.0320835 \\
(0.35)\end{array}$ \\
\hline Marital & 0.0311662 & -0.1063622 & 0.1106934 & -0.0370329 & $0.0024499^{* * *}$ & -0.001665 \\
\hline Status & $(0.28)$ & $(0.81)$ & $(1.33)$ & $(0.24)$ & $(9.50)$ & $\begin{array}{l}(0.02) \\
0.0128506^{* *}\end{array}$ \\
\hline $\begin{array}{l}\text { Household } \\
\text { Size }\end{array}$ & $\begin{array}{l}-0.0540272^{* *} \\
(2.31)\end{array}$ & $\begin{array}{l}0.05346^{* *} \\
(2.38)\end{array}$ & $\begin{array}{l}0.0050034 \\
(0.37)\end{array}$ & $\begin{array}{l}0.0861807^{* * *} \\
(3.31)\end{array}$ & $\begin{array}{l}-0.000439 \\
(0.36)\end{array}$ & $\begin{array}{l}* \\
(2.84)\end{array}$ \\
\hline $\begin{array}{l}\text { Farming } \\
\text { Status }\end{array}$ & $\begin{array}{l}0.070772 \\
(1.19)\end{array}$ & $\begin{array}{l}-0.0095129 \\
(0.13)\end{array}$ & $\begin{array}{l}-0.0955219^{* *} \\
(1.98)\end{array}$ & $\begin{array}{l}-0.0368531 \\
(0.45)\end{array}$ & $\begin{array}{l}0.0000424 \\
(0.10)\end{array}$ & $\begin{array}{l}0.051106 \\
(1.05)\end{array}$ \\
\hline $\begin{array}{l}\text { Non-farm } \\
\text { Income }\end{array}$ & $\begin{array}{l}2.64 \mathrm{E}-07 \\
(0.24)\end{array}$ & $\begin{array}{l}-2.84 \mathrm{E}-07 \\
(0.22)\end{array}$ & $\begin{array}{l}-1.36 \mathrm{E}-07 \\
(0.21)\end{array}$ & $\begin{array}{l}8.22 \mathrm{E}-07 \\
(0.59)\end{array}$ & $\begin{array}{l}-4.51 \mathrm{E}-09 \\
(0.29)\end{array}$ & $\begin{array}{l}-6.61 E-07 \\
(0.73)\end{array}$ \\
\hline $\begin{array}{l}\text { Educational } \\
\text { Level }\end{array}$ & $\begin{array}{l}0.084702^{*} \\
(1.65)\end{array}$ & $\begin{array}{l}-0.0340222 \\
(0.57)\end{array}$ & $\begin{array}{l}0.0548138^{* *} \\
(2.25)\end{array}$ & $\begin{array}{l}-0.0326631^{* * *} \\
(3.46)\end{array}$ & $\begin{array}{l}0.0003205 \\
(0.35)\end{array}$ & $\begin{array}{l}0.0164305 \\
(0.38)\end{array}$ \\
\hline Farm size & $\begin{array}{l}0.0275333 \\
(0.75)\end{array}$ & $\begin{array}{l}0.0150394 \\
(0.33)\end{array}$ & $\begin{array}{l}-0.0043043 \\
(1.38)\end{array}$ & $\begin{array}{l}0.0062264 \\
(0.12)\end{array}$ & $\begin{array}{l}0.0006839 * * * \\
(2.35)\end{array}$ & $\begin{array}{l}-0.0849333^{* *} \\
(2.75)\end{array}$ \\
\hline $\begin{array}{l}\text { Farm } \\
\text { Experience }\end{array}$ & $\begin{array}{l}-0.0106276^{* *} \\
(2.32)\end{array}$ & $\begin{array}{l}0.015951 \\
(4.16)\end{array}$ & $\begin{array}{l}-0.0043043 \\
(1.38)\end{array}$ & $\begin{array}{l}0.0159702^{* * *} \\
(2.99)\end{array}$ & $\begin{array}{l}0.0000161 \\
(0.29)\end{array}$ & $\begin{array}{l}0.0005288 \\
(0.18)\end{array}$ \\
\hline Interest rate & $\begin{array}{l}-0.0000384^{* *} \\
(2.16)\end{array}$ & $\begin{array}{l}-0.0000423^{* *} \\
(2.09)\end{array}$ & $\begin{array}{l}-.0000516^{* * *} \\
(4.53)\end{array}$ & $\begin{array}{l}-0.0000185^{*} \\
(1.93)\end{array}$ & $\begin{array}{l}-8.76 \mathrm{E}-07^{* * *} \\
(3.33)\end{array}$ & $\begin{array}{l}-.0000284^{* * *} \\
(3.46)\end{array}$ \\
\hline $\begin{array}{l}\text { Transaction } \\
\text { Cost } \\
\text { Depreciatio }\end{array}$ & $\begin{array}{l}-6.98 E-06 \\
(0.18)\end{array}$ & $\begin{array}{l}-3.35 \mathrm{E}-04^{* * *} \\
(7.56)\end{array}$ & $\begin{array}{l}3.11 \mathrm{E}-07 \\
(0.02)\end{array}$ & $\begin{array}{l}-0.0000286 \\
(0.55)\end{array}$ & $\begin{array}{l}-1.28 \mathrm{E}-06 \\
(0.36)\end{array}$ & $\begin{array}{l}-.0001336^{* * *} \\
(2.32)\end{array}$ \\
\hline $\mathrm{n}$ & $\begin{array}{l}-9.52 \mathrm{E}-06^{*} \\
(1.66)\end{array}$ & $\begin{array}{l}-3.47 \mathrm{E}-06 \\
(0.69)\end{array}$ & $\begin{array}{l}2.11 \mathrm{E}-06 \\
(1.15)\end{array}$ & $\begin{array}{l}9.43 \mathrm{E}-06 \\
(1.80)\end{array}$ & $\begin{array}{l}2.70 \mathrm{E}-07^{* * *} \\
(2.33)\end{array}$ & $\begin{array}{l}1.40 \mathrm{E}-06 \\
(0.63)\end{array}$ \\
\hline
\end{tabular}

Source: Field Survey Data, 2017

Notes: $* * *, * *, *=$ significant at $1 \%, 5 \%$, and $10 \%$ probability level, respectively. Figures in parenthesis $=\mathrm{z}$-values

The table shows the marginal effect of the model which measures the expected change in probability of a particular choice relative to a unit change in the independent variable.

In no credit source model, the coefficients of household size, farm experience, interest rate and depreciation were negatively significant while educational level was positive and significant. The results indicated that the average marginal effect of household size, farm experience, interest rate and depreciation on no credit source were $-0.0540272,-0.0106276,-0.0000384$ and -9.52E-06 respectively. This implies that as the household size and farm experience, interest rate and depreciation increases, the probability that the farmer will choose no credit source decreases by 5.4, 1.1, 0.004 and 0.00001 percentage points respectively. However, the coefficient of educational level was highly significant and positively correlated with the likelihood of choosing no credit usage. The result indicated that the average marginal effect of 
educational level on no credit usage was 0.084702 and this means that as the farmer's educational level increases, the likelihood of choosing no credit usage decreases by 8.4 percent. In banks model, the coefficient of age was significant and negatively correlated with the probability of choosing banks as a credit source. The result showed that the average marginal effect of age on banks was -0.015111 and this means that as the farmer's age increases, the probability that they would choose banks as credit source decreases by 1.5 percent. This is in line with the result of Fred et al (2013) who found age to be significant in determining farmers' access to credit. Similarly, the coefficient of interest rate and transaction cost was negative and the average marginal effect was -0.0000423 and $-3.35 \mathrm{e}-04$ respectively. This implies that as interest rate and transaction cost to obtain credit from banks increase, the probability of farmers obtaining credit from banks decreases by 0.004 and 0.034 percentage points respectively. However, the coefficient of household size was significant and positive. The average marginal effect of household size on banks was 0.0534600 and this implies that as the household size of the farmer's increase, the likelihood of farmers to choose banks as their credit source increases by 5.35 percent.

In the cooperative model, the coefficient of gender and family status were significant and correlated negatively. The result showed that the average marginal effect of gender and farming status were -0.1636855 and -0.0955219 respectively. This means that the likelihood of female farmers and part time farmers to choose cooperatives as their credit source is higher by 16.4 and 9.6 percentage points respectively. Similarly, the coefficient of interest rate was significant and negative. The average marginal effect of interest rate on cooperative was 0.0000516. This means that as the interest rate charged by cooperatives increases, the probability of choosing cooperative as a credit source decreases by 0.005 percent. However, the coefficient of educational status was positive and significant. The average marginal effects of educational status on cooperative gave 0.0548138 and this implies that as the educational status of farmers' increase, the likelihood of farmers to choose cooperative increases by 5.5 percent. This is in line with Nwaru and Onuoha (2010) who found that credit was significantly influenced by educational level, farming experience and membership of cooperatives/farmers' associations.

In the Esusu model, the coefficient of household size and farming experience were positive and significant. The results indicated that the average marginal effect of household size and farming experience were 0.0861807 and 0.0159702 respectively. This implies that as farmers' household size and farming experience increases, the likelihood that the farmer would choose Esusu increases by 8.6 and 1.6 percent respectively. However, interest rate and educational level is negative and significant. The average marginal effects of interest rate and educational level on Esusu were -0.0000185 and -0.0326631 . This implies that as the interest rate and farmers educational level increases, the probability that the farmers would choose Esusu as a credit source decreases by 0.002 and 3.3 percent respectively.

In the Moneylenders model, the coefficient of marital status and farm size was significant and correlated positively with the model. The result indicated that the average marginal effect of marital status and farm size on moneylenders were 0.0024499 and 0.0006839 respectively. This implies that the likelihood of married farmers to choose moneylenders as their credit source increases by 0.3 percent and as farm size increase, the likelihood of farmers to choose moneylenders as their source of credit increases by 0.07 percent. The result of farm size is similar to that of Omonona et al (2008). Also, the coefficient of depreciation was significant and positively correlated with the model with the average marginal effect of $2.70 \mathrm{e}-07$ and this means as the farmers assets depreciate, the likelihood of the farmers to choose credit from money lenders increases by 0.00003 percent. However, the coefficient of interest rate is 
negative with an average marginal effect of $-8.76 \mathrm{e}-07$. This means that as the interest rate charged increases, the likelihood of farmers to choose credit from this source decreases by 0.0001 percent.

In the family and friends model, the coefficient of age and farm size was significant and negatively correlated with the credit source. The result showed that the average marginal effect of family and friends on age and farm size were -0.006207 and -0.0849333 respectively. This means that as the farmers' age and farm size increase, the farmers' likelihood to obtain credit from family and friends decreases by 0.6 and 8.4 percent respectively. Also, the coefficient of interest rate and transaction cost were significant and negative. The average marginal effect of interest rate and transaction cost on family and friends were -0.0000284 and -0.0001336 respectively. This implies that as interest rate and transaction cost increases, the probability that farmers would take credit from family and friends decreases by 0.003 and 0.013 percent. However, the coefficient of household size is positive and significant. Results indicated that the average marginal effect of household size on family and friends was 0.0128506 and this means that as farmers' household size increase, the probability of getting credit from family and friends increases by 1.3 percent.

\section{CONCLUSIONS AND RECOMMENDATION}

In conclusion, credit availability lifts the affairs of any economic venture to greater height and Nigerian agriculture is no exception. This research has shown that there are certain disparities as to who or what class of farmers utilize the different types of credit. In view of the importance of farming in the economy, it has become necessary for government and every institution connected with agricultural development in Nigeria to continue to give the financing of agriculture attention it deserves and also strive to put an end to preferential treatment given to farmers at different cadres whilst assessing credit for utilization.

In line with the findings of this study and the need to make various credit sources readily available to farmers for utilization, the following recommendations were made:

1. Credit should be extended more to older respondents with low family size.

2. Credit institutions should adopt on-time and complete credit disbursement as a measure to reduce loan default and delinquency.

3. Credit institutions should moderate the high transaction cost and interest rate being charged for credit acquisition especially for rural farmers.

4. Extension services should be made available to farmers in the study area in order to increase the awareness of various credit sources and arouse the interest of farmers in the area in the use of credit.

\section{References}

Adeniji, A.A. (2008). Management accounting, $4^{\text {th }}$ edition, El-Toda Venture limited, Lagos, Nigeria.

Adewale, D.J. (2003). Youth Development for Agriculture and Rural Transformation in Nigeria. Policy Advocacy Role in Agricultural and Rural Transformation in Nigeria.

Adofu, I., Abula, M., \& Audu, S.I., (2010). An assessment of the effects of interest rate deregulation in enhancing agricultural productivity in Nigeria. Current Research Journal of Economic Theory; 2(2): 82-86.

Agbonlahor, M.U., Enilolobo, O.S., Sodiaya, C.I., Akerele, D. and Oke, J.T.( 2012):

Accelerating Rural Growth through Collective Action: Groups' Activities and Determinants of Participation in Southwestern Nigeria, Journal of Rural Social Sciences, 27(1):114-136.

Anjani, K.., Dhiraj K.S. \& Prabhat K. (2007), Performance of Rural Credit and Factors

Affecting the Choice of Credit Sources, Indian Journal of Agricultural Economics; Vol 7, No(3): pp 297- 312.

Ehigiamusoe, G. (2008). The Role of Microfinance Institutions in the Economy of Nigeria. Bullion 32(1) 17-25. 
Federal Ministry of Agriculture and Natural Resource (FMANR), (2010),National agriculture investment plan (2011-2014),ECDWAP/CAADP/Process, Federal ministry of agriculture and natural resources, Nigeria, pp 1-80.

Fred, Nimoh, Tham-Agyekum E.K.; \& M.S. Awuku (2013). "Factors Influencing Access of Poultry Farmers to Credit; The case of the Agricultural Development Bank (ADB) in Ga East Municipality, Ghana". Department of Agricultural Economics, Agribusiness and Extension, KNUST, Kumasi, Ghana.

Ibekwe, U.C., Eze, C.C, Onyemauwa C.S, Henri-Ukoha, A., Korie, O.C. \& Nwaiwu I.U. (2010), “Determinants of Farm and Off-farm Income Among Farm Households in South-east Nigeria, Academia ARENA 2(2), 1-4.

Ibekwe U.C., Chikezie C., Obasi P.C, Eze C.C.,Henri-Ukoha A. (2012). Profitability of garri processing in Owerri North Local Government Area of Imo State. ARPN Journal of Science and Technology,2(4):340-343

Igbalajobi, O. A.I. Fatuase \& I. Ajibefun (2013). “Determinants of Poverty Incidence Among Rural Farmers in Ondo state, Nigeria. Department of Agriculture and Resource Economics, Federal University of Technology, Akure, Ondo state, Nigeria.

John, C.I., \& Charles K.O., (2015). Agricultural Credit Sources and Determinants of Credit

Acquisition by Farmers in Idemili Local Government Area of Anambra state: Journal of Agricultural Science and Technology. B5 (2015): 34-43.

Mgbakor, M.N., Uzendu P.O., \&Ndubuisi D.O. (2014). Sources of Agricultural Credit to Small-scale Farmers in Ezeagu Local Government Area of Enugu state, Nigeria: Journal of Agriculture and Veterinary Science. Vol 7, issue 8, ver. 1,pp 01-08.

National Bureau of Statistics (NBS) (2010), The Nigeria Poverty Profile 2010 Report, National Bureau of Statistics, Abuja.

Nwaiwu J.C. (2015). Socio-Economic Factors Influencing Arable Crop Farmers' Adoption of Environmental Conservation Measures in South Eastern Nigeria. International Journal of Research in Agricultural and Forestry, Vol. 2(3): Pp. 20-25.

Nwaru, J. C. (2004). Rural Credit Markets and Resource Use in Arable Crop Production in Imo State of Nigeria. Ph. D. Dissertation, Michael Okpara University of Agriculture, Umudike, Nigeria.

Nwaru, J. C., Onyenweaku, C. E., Nwagbo, E. C., \& Nwosu, A. C. (2004). Determinants of rural farm loan repayment: implications for rural credit markets development in Imo State, Nigeria. Journal of Agricultural and Food Science, 2(1), 57-67.

Nwaru, J. C. \& Onuoha, R. E. (2010). "Credit use and technical change in smallholder food crop production in Imo State of Nigeria”. Journal of Science 3: 144-151.

Oboh, V. U. \& Ekpebu, I. D. (2011). "Determinants of formal agricultural credit allocation to the farm Sector by arable farmers in Benue State, Nigeria: Department of Agricultural Economics, Federal University of Agriculture, Makurdi. Nigeria". African Journal of Agricultural Research 6(1): 181-185.

Ojukaiye, E.O. (2001). Economic Analysis of Cassava Production in Three Local Government Areas of Kogi state. M.Sc Thesis, Department of Agricultural Economics and Rural Sociology, ABU, Zaria.

Omonona, B.T., Akinterinwa A.T., Awoyinka Y.A. (2008). Credit Constraint and output Supply of Cowan Farmers in Oyo state Nigeria. European Journal of Social Sciences. ;6:382-390

Omonona, B.T. Lawal, J.O. \& Oyinlana, A.O. (2010). Determinants of Credit Constraints, Conditions and Production Efficiency among Farming Households in South western Nigeria. In: Paper Presented at the Joint Third African Association of Agricultural Economists and Forty Eight Agricultural Economists Association of South Africa Conference, Cape Town, South Africa, 19-23 October 2010. pp.22-35 